\title{
Legal Consequence of the Cessation of the Life Insurance Premiums Payment by the Insured (A Case Study of Molly Situwanda and Panin Dai-Ichi Life)
}

\author{
Kenneth Kenneth ${ }^{1}$ Mella Ismelina Farma Rahayu ${ }^{1 *}$ \\ ${ }^{1}$ Faculty of Law, Universitas Tarumanagara, Grogol Petamburan, West Jakarta, Indonesia \\ *Corresponding author.Email: mellai@fh.untar.ac.id
}

\begin{abstract}
Human life in the modern era, makes humans often encounter risks in all aspects of their lives. In an effort to reduce the risks that will be faced, there is a method known as insurance. Insurance basically is an agreement between two parties, which is the insurer and the insured. Insurance agreement is an agreement where the insurer commited to bear a risk that will be faced by the insured, and the insured obliged to pay insurance premium to the insurer. Life Insurance is one of the most common insurance that society posses nowadays, that's because the life insurance give a protection to the insured family if one day the insured passed away. In the modern day, many cases happens where the insured failed to pay the life insurance premium to the insurer. In this condition will came a legal consequence to the both parties. The consequence appear because in this situation, the insured has breach the agreement. This thing happens because the insured has failed to pay the insurance premium. Which in the agreement, the insured has the obligation to pay the life insurance premiums to the insured for the risk transfer that the insured commited to take from the insurer. The legal consequence that appears because of this problem are that the agreement in considered to be over and the insured has lost all the benefits that they should have from the life insurance program, including the rights to claim to coverage fund.
\end{abstract}

Keywords: Life Insurance, insurer, insured, insurance premium, risk

\section{INTRODUCTION}

\subsection{Background}

In this modern era, when doing activities humans are tend to encounter a risk in every aspect of their life. The risks that often appear such as risk for being ill, risk to run to a accident, risk of death, and many more. Risk is the possibility of events that have a negative influence on the ability of a person or an institution to achieve its objectives.[1]. To reduce the risk there is a method known as insurance, which transfer the risk that someone will face to be bear by another person. Insurance is an agreement between two parties, which are the insurer and the insured, where insurance company (insurer) commited himself to compensate and / or pay an amount of fund (compensation) when the evenement happens, while the policy holder (the insured) has the obligation to pay insurance premiums to the insurance company.[2] In shorts insurance bind the insurer to cover a loss that the insured will faced in the future events. In Indonesia there are various types of insurance, such as health insurance, travel insurance, car insurance, life insurance, fire insurance, and many more. Life insurance is one of the most common insurance programs that the people posseses nowadays. In the life insurance agreement, there are rights and obligations that attached to both parties. The main rights of the insurer is to receive a life insurance premiums payment from the insurer and as the reciprocity of that rights, the insurer have obligations to commited himself to bear the risk that the insured will faced in the future. For the insured, the main right is to transfer the risk that they will faced in the future to the insurer, with the obligations to pay the life insurance premium to the insurer. Insurance has several benefits, including the first, which is to help people deal with risks that can occur at any time in everyday life. This provides peace and comfort to the community when carrying out their daily activities, because the risks experienced will be transferred to the insurance company. The second is that insurance is a company with a large enough fundraising, which can be used to help and support development in a country. The last one is insurance as a means / means to reduce risks in carrying out a development. Either from the risks faced by workers or risks that will be faced financially by construction companies in development.Insurance first known in Indonesia during the Dutch colonial period to be precise in 1853. At that time to support the plantation and trade business in Indonesia, they established the first general insurance company in Indonesia under the name Bataviasche Zee End Brand Asrantie 
Maatschappij. The insurance program provided by the insurance company is in the form of fire protection insurance and transportation insurance. After a period of independence the insurance company owned The Dutch named NV Assurantie Maatshappij De Nederlandern and Bloom Vander EE and De Nederlanden Van 1845 were nationalized to become PT. Bendasraya Insurance and PT. Jiwasraya Insurance. The development of modern insurance in Indonesia began when in the 1980s many modern insurance companies were established in Indonesia. Companies that provide insurance companies include Sinar Mas Insurance, Prudential, CIGNA, Avrist AXA Mandiri, AIA Financial and Allianz. Where these companies offer various protection programs to investment. Regulations for life insurance in Indonesia regulated in burgerlijk wetboek van koophandel articles 302-306, Undang-Undang Nomor 40 tahun 2014 about Insurance, and in articles about agreement in burgerlijk wetboek. That because an insurance basically is an agreement, so that every articles in burgerlijk wetboek that regulate about an agreement also aplied for an insurance agreement, such as article 1320 that contains terms of the validity of an agreement and also in article 1338 that regulate about agreement is binding the parties that made the agreement as an constitution or known as principle of pacta sunt servanda. Nowadays, there are many case where the insured with a bad intention stop paying the life insurance premiums but still make a claim when a risk happens to them. This things become a problem in insurance industry because there obscurity for the insurance company, regarding their responsibility to pay or not to pay the compensation fund to the insured who already breach the life insurance agreement in the first place by not doing their obligations to pay the life insurance premiums to the insurer. Based on the description above, appointed an article with the title "Legal Consequence of the Cessation of The Life Insurance Premiums Payment by the Insured"

\subsection{Problems}

Based on the background that the author has described, the author draws a problem, namely:

1. What is the legal consequence if the insured stop paying the life insurance premiums?

2. What is the legal consequence for Molly Situwanda from stop paying life insurance premiums?

\subsection{Research Method}

\section{Research Type}

The type of research that researchers use in this research is a type of normative research because this research analyzes existing legal issues by reviewing laws that are related to legal issues raised by the author and conducting a study of a court decision related to these legal issues. Normative Legal Research is one type of legal research that makes law as a norm system building, namely regarding the principles, norms, rules of legislation, court decisions, agreements and doctrines (teachings).[3]

\section{The Nature of Research}

The nature of this research is prescriptive because this research provides a prescription of what should or should be about the legal issues raised. [4]

\section{Types of Data}

In legal research there is no data, but legal materials as research sources: [5]

a. Primary Legal Materials

The primary legal materials used in this research consist of laws and regulations and court decisions. The primary legal materials used include: Civil Code (KUHPer), Commercial Code (KUHD), and UndangUndang Nomor 40 tahun 2014 concerning Insurance,

b. Secondary Legal Materials

Secondary legal materials used in this paper consist of legal books including legal theses and legal journals. Besides that, dictionaries and opinions or comments on court decisions. [6]

4. Research Aproach

The research approach used is the statute approach, which is an approach that is carried out by examining all laws and regulations or regulations that are related or have a relationship with the legal issue being handled. [7]

\section{Data Collection Techniques}

This research is a type of normative research, so the data collection technique used by researchers is Library Research, namely library research on primary legal materials and secondary legal materials.

\section{DISCUSSION}

\subsection{Definition and General Theory of The Agreement and Insurance}

The definition of agreement is regulated in Article 1313 which reads: "An agreement is an act whereby one or more parties bind themselves to one or more people". Soebekti defines an agreement as an event in which a person promises to another person or where the two people promise each other to do something.[8] Meanwhile, according to KRMT Tirtodiningrat an agreement is a legal act based on an agreement between two or more people to cause consequences. law that can be enforced by law.[9] So that a complete agreement can be defined as a legal act, in which one or more people bind themselves or bind themselves to one or more people.

According to Article 1320 of the Civil Code, four conditions are required for the validity of the agreement:

1) Agree on them who bind themselves;

2) Competent to make an agreement;

3) Regarding a certain matter;

4) A cause that is lawful.

The first and second terms are subjective terms, this is because these terms are about the subject who made the agreement. While the third and fourth conditions are 
objective requirements, this is because they are related to the object of the agreement. [10] Insurance in Dutch is called "Verzekering" or also means coverage. Juridically, the definition of insurance or coverage according to Article 246 of the Indonesian Commercial Code (KUHD) is an agreement whereby an insurer binds himself to an insured, by receiving a premium, to compensate him due to a loss, damage or loss of profit. expected, which may be suffered because of an indefinite event. Basically, insurance is a risk transfer that will be faced by a person to the insurance company which is offset by a premium payment by that person to the insurance company. From this understanding it can be understood that in insurance there are four elements that must be present, namely: [11]

1. An agreement that underlies the formation of an agreement between two parties (the insured and the insurer) which simultaneously creates a civil relationship;

2. Premium in the form of money that the insured can pay to the insurer;

3. There is compensation from the insurer to the insured if a claim occurs or the agreement period is over;

4. There is an event (evenement / accident) that does not necessarily occur, which is stated because of a risk that may or may not be experienced.

In an Insurance Agreement, the agreement that has been reached by the insured party and the insurer regarding the risks to be insured is stated in a document or deed called a policy. This is explained in Article 255 of the Commercial Code which states that: "Insurance must be made in writing in a deed called a policy." An insurance policy is the main legal document made legally fulfilling the requirements contained in Article 1320 of the Civil Code and Article 251 of the KUHD. The policy is not a contract or insurance agreement, but rather as evidence of the existence of the contract or agreement. This is explained in Article 258 of the KUHD paragraph (1) and (2) which states: "In order to prove the closure of the agreement, written evidence is required, however, other means of proof may also be used, when there is already an initial written proof. " and "However, special provisions and conditions, if a dispute arises, within the period between the closure of the agreement and the submission of the policy, it is proven by all means of evidence, but with the understanding that all matters are covered by the provisions of the provisions. Law on threats to be canceled, it is mandatory to mention it clearly in the policy, it must be proven in writing." An insurance agreement effectively binds both parties when the insurer and the insured reach an agreement. That thing explains in article 257 Commercial Code (KUHD) which is the contract is considered to have occurred when the insured party and the insurer reach an agreement (consensus). Where article 257 KUHD reads: "The insurance agreement is issued immediately after it is closed; the reciprocal rights and obligations of the insurer and the insured come into force from then on, even before the policy is signed. " "The closing of the agreement issues an obligation for the insurer to sign the policy within a specified period and hand it over to the insured." Meanwhile, an insurance agreement may terminate due to the following matters: [12]

1. When the insurance has been completed by the time that has been agreed upon.

2. In the event of total destruction or a loss which reaches the amount insured. (in the case of life insurance coverage ends when the insured object dies).

3. When the insurer (the insurer) is released by his verzekerde (the insured)

4. If it fails, it fails because:

a) The object of harm is no longer in danger (if there is no further possibility, that the insured will lose against the loss where the insurance has been held).

b) Additional danger

c) If the insurance promise is terminated, because one of the parties is in default.

In an insurance agreement, there are applied principles about insurance agreement which are : [13]

a) Insurable Interest

b) Utmost Good faith

c) Indemnity Principle

d) Subrogation Principle

e) Causaliteit Principle

f) Contribution Principle

g) Cause Principle

\subsection{Rights and Obligations of the Insurer and the Insured in Insurance Agreement}

The subjects in an insurance agreement are parties who play an active role in carrying out the agreement. In general, the insurer is the party who receives the transfer of risk where by receiving a premium, promises to compensate or pay the agreed amount of money, in the event of an unforeseen event that results in losses to the insured. Both of the parties in an insurance agreement have rights and also obligations. In order to perform the agreement both parties must not be negligent on their obligation to each other. Rights owned by the insurer includes: [14]

a. Demand payment of premiums to the insured in accordance with the agreement.

b. Ask the insured for true and complete information relating to the object insured to him.

c. Has a premium and even demands it in the event that the promised event occurs but is caused by the insured's own fault. (Article 276 KUHD)

d. Has a premium that has been received in the event that the insurance is canceled or canceled due to fraudulent acts of the insured. (Article 282 Commercial Code)

e. Reinsurance to other insurers, with the intention of sharing the risks they face. (Article 271 Commercial Code)

Besides the of rights, the insurer also has an obligation which includes: [15]

a. Provide compensation or give an amount of money to the insured if the agreed event occurs, unless there is 
something that could be a reason to release from that obligation.

b. Signing and submitting the policy to the insured (Articles 259, 260 Commercial Code).

c. Return the premium to the insured if the insurance is canceled or canceled, provided that the insured has not borne the risk partially or completely (restorno premium, Article 281 Commercial Code).

d. In fire insurance, the insurer must replace the costs needed to rebuild if the insurance is so agreed (Article 289 Commercial Code).

According to article 250 of the Commercial Code, those who have an interest in the insured object can be the insured. If the interest does not exist, the insurer has no obligation to compensate the insured for damages. The insured in an insurance agreement has rights and obligations that must be carried out by him, so that if an unexpected event occurs which is guaranteed in the policy, the insurer can carry out his obligations in accordance with the applicable policy. In the insurance agreement the insured's rights are including: [16]

a. Demands that the policy be signed by the insurer (Article 259 Commercial Code).

b. Demanded that the policy be immediately submitted by the insurer (Article 260 Commercial Code).

c. Asking for compensation Apart from having rights, the insured in an insurance agreement also has obligations.

Besides of the rights, the insured party also have obligations which include: [17]

a. Pay a premium to the insurer (Article 246 Commercial Code).

b. Provide correct information to the insurer regarding the insured object (Article 251 Commercial Code).

c. Prevent or make efforts so that events that may cause harm to the object insured do not occur or can be avoided; If it can be proven by the insurer, that the insured did not try to prevent the occurrence of this incident, it could be one of the reasons for the insurer to refuse to provide compensation, even on the contrary, to demand compensation from the insured (Article 283 Commercial Code).

d. Notify the insurer that an incident has happened to the insured object, along with the prevention efforts.

\subsection{Life Insurance Policy Status if The Insured No Longer Pays the Life Insurance Premiums}

Insurance basically is an agreement between two parties, namely the insured who is usually a customer and the insurer, who is usually an insurance company. So that in an insurance agreement also applies general provisions regarding the agreement, such as the validity of an agreement. An insurance agreement is an agreement between two parties, namely the insured and the insurer, where the insured is obliged to pay a premium to the insured to get coverage if a damage or loss of profits is expected that is not certain will occur in the future.[18] In an insurance agreement usually contains conditions - General terms regarding coverage and the rights and obligations of each party in an insurance agreement which is set forth in an insurance policy. Insurance Policy is a document that contains an agreement regarding an insurance coverage between the insured and the insurer regarding the risk that will be transferred, offsetting the premium payment carried out by the insured to the insurer in return. In other words, the insurance policy contains the rights and obligations of the parties in an insurance agreement. In general, the rights of the insured in the insurance agreement are the right to transfer the risk that will be faced at a certain time during the insurance agreement period. The insured here has the right to transfer a risk that he might experience in the future to the insurer. Apart from rights, the insured in an insurance agreement also has an obligation. In general, the insured party's obligation is to pay premiums to the insurer as a form of reciprocity from receiving the transfer of risk by the insurer. Premium payment is the main obligation of the insured party. This is because if the premium payment is not made to the insurer, the insured can be said to have committed an act of broken promise or default which could terminate an agreement. Insurers in an insurance agreement also have their respective rights and obligations. In general, the right of the insurer is to receive premium payments made by the insured as a reciprocal form of receiving the transfer of risk by the insurer. Premium payment received by the insurer will be accompanied by a guarantee or coverage of a risk that will be faced by the insured during the coverage period. Meanwhile, the obligation attached to the insurer is to accept the transfer of risk faced by the insured when the insurance period is valid or active. In other words, in an insurance agreement the insurer is obliged to bear or take over a loss or loss of profit that should be received by the insured which is offset by the payment of a premium by the insured to the insurer. Both parties to an insurance agreement, both the insured and the insurer, must not be negligent in carrying out their obligations. If the insured party is negligent in carrying out its obligations, namely making premium payments to the insurer, this will result in the insurance policy entering a grace period. Grace period itself is the period of insurance premium payment after the due date. In general, a grace period of 30 days, 45 days, or 60 days after the due date depends on the agreement between the insured and the insurer in the coverage agreement that is stated in an insurance policy. In the grace period, the insured is obliged to pay his insurance premiums that are payable within the period agreed upon in the insurance policy, either 30 days, 45 days, or 60 days. If during the grace period the insured does not pay premiums to the insurer, then the investment value or unit of the insurance policy will be deducted. The deduction of the investment value or unit can be done on condition that the investment value or unit is sufficient to cover the premium cost of the insurance policy. If the investment value is insufficient to pay the premium, the insurance policy will enter a lapse status or be canceled on the condition that the paid premium cannot be returned.[19] 


\subsection{Legal Consuquences for The Insured if They Stop Paying the Life Insurance Premiums}

In a legal relationship between two parties, it will certainly create rights and obligations for each party. In fact, the exercise of rights and obligations in a legal relationship is a fairly common problem. This is due to frequent negligence in carrying out obligations in a legal relationship. Failure to carry out these obligations is known as broken promise or default. Forgo promises or defaults is the failure or inability of one of the parties in a legal relationship to fulfill its obligations. The act of breaking a promise or in default will result in legal consequences or consequences for the party who broke the promise or default. Default or broken promise usually exists in a legal relationship based on an agreement. In the life insurance agreement, the policyholder's obligation is to pay the insurance premium to the insurance company. This is a form of reciprocal transfer of risk by the policy holder to the insurance company. However, policyholders often neglect their obligations, namely paying premiums to the insured. The premium itself is the amount of payment contained in the life insurance policy and has been approved by the policy holder to be paid to the insurance company as a form of reciprocity for the transfer of risk received by the insurance company from the policyholder. In other words, the payment of the premium from the policy holder to the insurance company is a major obligation and if it is not implemented it will result in a legal consequence or consequence for the life insurance policy holder. Failure to carry out the policyholder's obligations in an insurance agreement, namely paying premiums to the insurance company, will cause a consequence or legal effect that will be very detrimental to the policyholder. Where the legal consequences or consequences that will arise are that his life insurance policy will enter into a lapse / inactive status. In the status of a policy that is lapse or inactive, the life insurance agreement that occurs between the insurer and the insured will automatically end. This will cause the policyholder to lose the benefits he should receive when entering the insurance agreement. This is because the policyholder here has been negligent in carrying out their obligations and committed a broken promise or default. When the policy is in a lapse status or is inactive, if there is a risk or loss, the insurance company is no longer under its obligation to bear or take over the risk or loss faced by the policy holder. This is because the insurance agreement is considered to have ended due to the insured's failure to fulfill his obligation to pay the premium. So that if a claim is filed by a policyholder in a policy status, the claim will be rejected by the insurance company, because the insurance agreement is deemed to have ended and the insurance company, which in this case acts as an insurer, has no obligation or responsibility for the insurance agreement and the insured party.

\subsection{Legal Consuquences for Molly Situwanda by Stop Paying the Life Insurance Premiums}

In the case between Panin Dai-Ichi Life Life Insurance Company and Molly Situwanda, Astiang who is the husband of Molly Situwanda is the holder of a life insurance policy issued by Panin Dai-Ichi Life Life Insurance Company. Where he has participated in the life insurance program issued by the Panin Dai-Ichi Life Life Insurance Company since 2010 with a premium payment of $\mathrm{Rp}$. $1,500,000$, - per month. It is known that premium payments did not go smoothly because there were 10 times the policy went into lapse status but was successfully restored. However, when the policy enters into lapse status on the 11th time, the policy status is not restored until Astiang as the policy holder dies. After being investigated, Astiang as the policy holder no longer made premium payments since the due date, namely on December 28, 2016. Premium payments after the due date were made by deducting the value of the investment / unit, but deducting the value of the investment / unit was only able to cover premium fee until October 15, 2018 and since then the policy has entered into lapse status. On April 12, 2019, Astiang as the policy holder passed away. However, when Astiang passed away, his life insurance policy status was already in a state of inactivity or lapse. This is because there has been no recovery effort from the policyholder since the policy lapse on October 15, 2018. When Molly Situwanda made a claim for her husband's life insurance policy, the claim was rejected by Panin Dai-Ichi Life Life Insurance Company through a letter with number 021 / CCA / 07.2019 dated 12 July 2019. The rejection was made by the Panin Dai-Ichi Life Life Insurance Company on the grounds that Astiang's life insurance policy was in lapse status since 15 October 2018 and there were no requests for policy restoration and premium payments to Panin Dai-Ichi Life Life Insurance Company since that date. After Astiang's life insurance policy goes into a lapse or inactive state, Panin Dai-Ichi Life Life Insurance Company in good faith has tried to contact Astiang. This was done by the Panin Dai-Ichi Life Life Insurance Company three times. The first is the Panin DaiIchi Life Life Insurance Company contacting Astiang by sending an SMS (Short Message Service) to the number registered in the policy Life insurance is a phone number that can be contacted, where in the SMS (Short Message Service) Customer Care Panin Dai-Ichi Life Life Insurance Company informs Astiang as a policy holder that the status of his life insurance policy is entered into lapse status due to non-payment policies received by Panin Dai-Ichi Life and Astiang Life Insurance Companies are requested to immediately contact the Call Center Number of the Panin Dai-Ichi Life Life Insurance Company to take care of their life insurance policy which is in a lapse state. After that Astiang was again contacted by sending an official letter sent to the correspondence address registered in the life insurance policy, namely Komp. Tirto Sari Permai No. A3, Medan. Where in the letter also informs that the status of his life insurance policy is included in the status lapse. However, the letter did not reach Astiang due to a change in 
the correspondence address from Astiang. Thirdly, Panin Dai-Ichi Life Life Insurance Company contacted Astiang by telephone and explained that his life insurance policy had gone into a lapse state. Astiang accepted the explanation, and at the same time Astiang said that there had been a change in correspondence address but the explanation for the new address was not complete. Change of correspondence address could not be made. Although notification was made to Astiang that his life insurance policy was entered into a lapse due to no premium payment received by Panin Dai-Ichi Life Life Insurance Company since December 28, 2016 and the investment / unit value was insufficient to cover premium costs. , still no premium payments are made for the life insurance policy. As a result, the insurance policy remains in a lapse state or is inactive until Astiang as the policy holder dies. The status of Astiang's life insurance policy when Molly Situwanda filed a claim was in a state of lapse since 15 October 2018 and there were no efforts to recover and pay the premium back from the policyholder until she died. It can be seen that in this case the policyholder has broken the promise or default, namely by not paying the premium to the insurance company which is the main obligation of a policyholder in an insurance agreement. As a result of the act of breaking the promise made by Astiang as the policy holder, namely not paying premiums to the life insurance company, the status of Astiang's life insurance policy becomes inactive / lapse. The consequence of his life insurance policy which is in lapse status is that he loses the benefits he should have received by joining the life insurance program issued by the Panin Dai-Ichi Life Life Insurance Company. Although he has paid premiums from 2010 to 2016, in the last few months he has been negligent in carrying out his obligation to pay premiums to insurance companies which caused his life insurance policy to go into lapse status and he lost the benefits of the insurance program. the soul it follows. It can be seen that the status of Astiang's life insurance policy was already in a lapse condition even before he died and Astiang had been informed by Panin Dai-Ichi Life Life Insurance Company and knew that his life insurance policy was in a lapse state. Without any effort from Astiang or Molly Situwanda to recover the life insurance policy, Molly Situwanda made a claim on the life insurance. Whereas since the initial notification regarding the status of the policy that has entered into a lapse state there has been no attempt to restore the status of the life insurance policy and by the time the policy was almost 6 months after the policy is in a lapse / inactive condition, the insurance claim is made by Molly Situwanda as the beneficiary of the insurance policy. This claim was of course rejected by the Panin DaiIchi Life Life Insurance Company, because the policy status was already in a state of inactive / lapse so that the insurance agreement ended as a result of the act of default by Astiang, namely not making premium payments to the Panin Dai Life Insurance Company. Ichi Life. With the termination of the life insurance policy, Molly Situwanda as the beneficiary of the life insurance policy also loses her right to receive and claim the sum insured if the insured person in this case is Astiang or Molly Situwanda's husband dies. The sum insured is Rp. 270,000,000, - however Molly
Situwanda was unable to claim the sum insured because the life insurance agreement that was followed by her husband, namely Astiang, ended due to the act of default, namely not paying the premium at the specified time. The rejection of claims made by the Panin Dai-Ichi Life Life Insurance Company has strong and clear reasons. This is because the life insurance policy of Molly Situwanda's husband is already in a lapse condition which causes the life insurance agreement to end, which causes the benefits that should have been obtained by Molly Situwanda as the beneficiary of the life insurance policy. This is due to the absence of premium payments to the Panin Dai-Ichi Life Life Insurance Company since the due date, which is 15 October 2018 and causes the policy to enter into lapse status and the life insurance agreement ends. So that the Panin Dai-Ichi Life Life Insurance Company no longer has the obligation and responsibility for the life insurance policy. Besides that, the claim made by Molly Situwanda can be said to be unfair in implementing it insurance agreement, this is because he made a claim when he stopped carrying out his obligations in the life insurance agreement, namely making life insurance premium payments to Panin Dai-Ichi Life Life Insurance Company. Therefore, the rejection of claims made by the Panin Dai-Ichi Life Insurance Company is the right solution to this case.

\section{CLOSING}

\subsection{Conclusion}

Based on the results of the studies that have been carried out and based on the theories that have been put forward, the author can draw a conclusion, namely

1. In a life insurance agreement, both the policyholder (the insured) or the insurance company (the insurer) have their respective rights and obligations. The policyholder has the main obligation to pay premiums to the insurance company as a form of reciprocity from the transfer of risk received by the insurance company. If the policyholder does not pay the premium to the insurance company, the status of the policy holder's insurance will enter into a grace period. If after the grace period has passed, the policy holder's life insurance policy status will enter into a lapse / inactive state. In a condition where the policy is not active / lapse due to non-payment, it will certainly cause legal consequences for the policy holder and the insurance company. For policyholders, the legal result that arises is the loss of rights that should have been obtained by participating in a life insurance program organized by an insurance company, one of which is the loss of the right to receive sum insured if the policyholder dies at any time. So even if the beneficiary submits a claim when the policyholder dies, the claim will be rejected because the policy status is already inactive and the rights that should be obtained by the beneficiary are lost.

2. Molly Situwanda as the beneficiary of the life insurance policy receive a legal consequence from stop paying the life insurance premiums which is the termination of the 
life insurance policy. With the termination Molly Situwanda have lost all the benefits she should get by enrolled into a life insurance programs. This because in Molly Situwanda and Panin Dai-Ichi Life Case the insured has breach the agreement in the first place by stop paying the life insurance premiums.

\subsection{Suggestion}

Based on the above conclusions, the following suggestions can be given:

1. Policyholders should pay more attention to the obligations that must be carried out by them in an insurance agreement. This is so that there is no negligence in carrying out its obligations, where the result of the negligence causes losses to the policyholders themselves.

2. For insurance companies, you should explain more clearly and in detail to policyholders and beneficiaries about the obligations that must be carried out by them in a life insurance agreement.

\section{REFERENCES}

[1] S. Hayati, Manajemen Risiko untuk Bank Perkreditan Rakyat dan Lembaga Keuangan Mikro, (Yogyakarta: Andi, 2017), 2.

[2] R. Antasari, Fauziah, dan M. S. Is, Hukum Ekonomi di Indonesia, (Jakarta: Kencana, 2020), 172.

[3] M. N. D. Fajar dan Y. Achmad, Dualisme Penelitian Hukum Normatif \& Empiris, Cetakan ke-4. (Yogyakarta: Pustaka Pelajar, 2017), 34.

[4] P. M. Marzuki, Penelitian Hukum Edisi Revisi, Cetakan ke-13. (Jakarta: Kencana, 2017), 83.

[5] P. M. Marzuki, Penelitian Hukum Edisi Revisi, Cetakan ke-13. (Jakarta: Kencana, 2017), 181.

[6] P. M. Marzuki, Penelitian Hukum Edisi Revisi, Cetakan ke-13. (Jakarta: Kencana, 2017), 195-196.

[7] P. M. Marzuki, Penelitian Hukum Edisi Revisi, Cetakan ke-13. (Jakarta: Kencana, 2017), 133.

[8] A. Y. Hernoko, Hukum Perjanjian Asas Proposionalitas dalam Kontrak Komersial, (Jakarta: Kencana, 2014), 15.

[9] A. Y. Hernoko, Hukum Perjanjian Asas Proposionalitas dalam Kontrak Komersial, (Jakarta: Kencana, 2014), 16.
[10] Sidharta dkk, Aspek Hukum Ekonomi \& Bisnis, (Jakarta: Kencana, 2018), 17.

[11] I. Yikwa, "Aspek Hukum Pelaksanaan Perjanjian Asuransi", Lex Privatum, Vol.III No. 1, Maret 2015, 135.

[12] N. Y. Pandansari, "Pelaksanaan Hak dan Kewajiban Para Pihak dalam Perjanjian Asuransi Kecelakaan Diri di PT. Asuransi Jasa Indonesia (PERSERO) Kantor Cabang Semarang", (Semarang: Universitas Diponegoro, 2009), 52.

[13] T. Rastuti, Aspek Hukum Perjanjian Asuransi, (Yogyakarta: Pustaka Yutisia, 2011), 47.

[14] N. Y. Pandansari, "Pelaksanaan Hak dan Kewajiban Para Pihak dalam Perjanjian Asuransi Kecelakaan Diri di PT. Asuransi Jasa Indonesia (PERSERO) Kantor Cabang Semarang", (Semarang: Universitas Diponegoro, 2009), 21.

[15] N. Y. Pandansari, "Pelaksanaan Hak dan Kewajiban Para Pihak dalam Perjanjian Asuransi Kecelakaan Diri di PT. Asuransi Jasa Indonesia (PERSERO) Kantor Cabang Semarang", (Semarang: Universitas Diponegoro, 2009), 22.

[16] N. Y. Pandansari, "Pelaksanaan Hak dan Kewajiban Para Pihak dalam Perjanjian Asuransi Kecelakaan Diri di PT. Asuransi Jasa Indonesia (PERSERO) Kantor Cabang Semarang", (Semarang: Universitas Diponegoro, 2009), 24.

[17] N. Y. Pandansari, "Pelaksanaan Hak dan Kewajiban Para Pihak dalam Perjanjian Asuransi Kecelakaan Diri di PT. Asuransi Jasa Indonesia (PERSERO) Kantor Cabang Semarang", (Semarang: Universitas Diponegoro, 2009), 24.

[18] J. R. Latumaerissa, Bank dan Lembaga Keuangan lain, (Jakarta: Salemba Empat, 2011), 447.

[19] A. A. G. Agung, N. K. Dunia dan I K. Markeling, 2014, "Peranan Polis Asuransi Jiwa Dalam Penuntutan Klaim (Studi Pada Pt. Prudential Life Assurance Denpasar)", Kertha Semaya, Vol. 02, No. 01, Februari, 2014, 3. 